\title{
Computer Literacy In Undergraduate Business Education: The Case For The Adult Fast Track Programs
}

Juan Carlos Barrera, Elmhurst College, USA

\begin{abstract}
Industrialized nations have invested a great deal of public and private resources to facilitate access to information technologies (ITs) and to adjust their cultures and societies to them. These efforts are commonly associated with the idea of expanding computer literacy from higher education institutions to business organizations. Computers have fundamentally altered how we live and work, as well as how we learn and have transformed the world into a global community. Moreover, business organizations have struggled to train and to turn their workforce into a computer literate group that keeps abreast of changes in computing and information technologies, since most of the work does not rely on standardized literacy levels to perform well. This paper presents an examination on current computer literacy skills between groups of adult students enrolled in accelerated undergraduate business programs in the USA and in Germany. Special emphasis is granted to the discussion of the similarities and differences found in computer literacy skills and the implications associated with having literate and illiterate groups in the workplace.
\end{abstract}

Keywords: Computer Literacy; Literacy Skills; Literacy Differences

\section{INTRODUCTION}

$\mathscr{F}$ $\mathrm{n}$ recent years, computer information systems have experienced substantial growth and, consequently, attaining acceptable literacy levels has become a necessity (Kim \& Keith, 1994). Technology changes by leaps and bounds, existing skills become antiquated, and there is no migration path to new skills...to adapt to changes in the new technologies (NRC, 1999, p. 2). Lankshear (1997) found that computer literacy skills in light manufacturing cooperatives are oriented toward modern business practices and that basic computer literacy skills become irrelevant when the local market is open to global competition and the workforce is displaced. However, it is difficult for researchers to identify specific factors that cause people to accept and use new information technologies in their daily activities (King \& He, 2006). In years preceding the rising of the new technological era, Lucas (1976) suggested that individual and group behavioral factors have a strong influence in the IT adoption. Individuals learn from their behaviors and values and from their social interactions (Demiray, 2010). Consequently, differences and similarities may be found in learning and computer literacy levels in different environments.

During the 1980s, workers who gained access to a personal computer became the largest group of end-users throughout organizations (Winter, Chudoba \& Gutek, 1997). Consequently, they became more productive by assuming new responsibilities in their workplaces (Gerrity \& Rockart, 1986). However, Davis (1991) stated that actual productivity improvements in white collar workers were not the result of the introduction of new technologies in the workplace. Productivity improvements reflected increasing awareness of the new technologies and its potential application in the workplace.

Workers with higher computer literacy levels are able to use their computers in more sophisticated manners (McGrath, 1990). Conversely, the lack of computer literacy severely underutilizes equipment and diminishes desired results. Andersen (1990) suggested that computer literate workers possess both concrete and abstract knowledge of 
computers and are able to apply their knowledge to new situations without experiencing hardship. In addition, Branchean \& Wetherbe (1987) concluded that workers will experience different technology adoption levels in organizations with decentralized forms of work.

Winter, Chudoba \& Gutek (1997) suggested that computer knowledge can be learned in schools. However, workers depend more on business organizations to update computer knowledge as needed to perform their work rather than in higher education institutions to provide further training on computer literacy. Furthermore, Brock \& Thompsen (1992) suggested that access to computers at home and other technologies also influence computer familiarity of individuals and therefore computer literacy levels. In addition, Karsten \& Roth (1998) stated that although a wide variety of computer experiences enhance students' perceptions of their computer competencies, only those experiences that develop or enhance the specific computer skills defined in a particular context are likely to have an impact on computer literacy levels and performance.

Wallace \& Clariana (2005) stated that many colleges have decided to eliminate computer literacy courses based on the assumption that incoming students possess adequate computer skills. Students are now expected to embrace all computer-based innovations in their daily lives to complete all kind of tasks. However, before putting beginning students at risk by eliminating introductory computer courses, it seems critical to validate the value of such courses and the literacy level attained upon completion of computer education (Lynam, 2003, Pierce, Lloyd, \& Solak, 2001).

Higher education institutions continue to review their curriculums to ensure that students are offered degrees that will equip them well for life in a world of fast-paced technological change (Recker \& Alter, 2012). Many of the changes in curriculums reflect growing concern for information technology and computer-related technologies (Miliszewska, Venables, \& Tan, 2010). However, little attention is granted to computer literacy skills since information literacy concepts have claimed center stage in main information technology (IT) research (Venables \& Tan, 2009). Moreover, Hunt \& Perrault (1999) noted that educators are facing challenges in identifying, developing, and designing a curriculum that will prepare undergraduate students for work in the future.

Marshall (1993) suggested that educators must be involved in curriculum development that considers jobs for tomorrow and fast-changing labor demands in the future. Computers are used in different ways and modern needs have redefined their purpose and applications. Moreover, there is little evidence of research conducted to determine the computer competencies needed by business students to successfully join the workforce. Lastly, Jury (1999) asserted that computer literacy education is a need that resulted from the economic, social and political pressures that continuously increase. Consequently, it is in the best interest of companies to maintain a computer literate workforce as workers will become more productive and they will assume new roles during their tenure at organizations (Winter, Chudoba \& Gutek, 1997).

\section{PURPOSE OF THE STUDY}

The level of computer literacy is an important variable in a number of settings. Self-reported computer literacy provides some insights into the different attitudes towards adopting new changes in the workplace as they relate to technological progress and advance. This paper presents an examination on current computer literacy skills between groups of adult students enrolled in accelerated undergraduate business programs in the USA and in Germany. Further, it explores the similarities and differences found in computer literacy levels between the American and the German adult business students.

\section{LITERATURE REVIEW}

Business organizations need employees with updated knowledge and skills. Today's dynamic environments rely on the workforce to keep up with technological changes and to self-teach about such changes (Hill, 2006). The age of information technology has transformed all economies of the world and it has redefined the role of individuals in business organizations. Moreover, the diverse generational composite has embraced new information technologies in different ways (Hill, 2006). While some individuals continue to resent changes in the workplace, others embrace it as the new way to achieve higher efficiencies and innovations. 
The concept of computer literacy has changed over the past two decades. Research focuses more on information literacy rather than computer literacy. The evolution of computer systems and the rising of other technology devices have redirected the attention of researchers toward information technology (Banta \& Howard, 2004; O'Connor, 2007). Further, although not everyone is exposed to the same level of information technology in business organizations, we can assert that everyone is in direct contact with a computer in today's business environment. Moreover, the study of computer literacy has been instrumental in determining the impact of technology on increasing productivity and efficiency levels (Sharkey, 2006). Therefore, it is important to assess computer literacy levels of different groups to better understand how individuals have developed new skills through self-teaching of new knowledge to keep abreast and current in business organizations.

Definitions for computer literacy vary from the ability to self-teach and learn arbitrary new programs or tasks as they are encountered (Oni, 2000) to the computer knowledge and skills of individuals in different professions (Kay, 1990; Norales, 1987). Childers (2003) viewed computer literacy as basic computer skills that individuals have. Norman (1984) stated that four levels compose computer literacy: basic understanding, usage of computer, program a computer, and computer science understanding. In addition, Bolter (1991) suggested that the term "computer literacy" has been taken to mean either the ability to operate a computer (how to insert the disks, how to call up a program, perhaps how to type into a word processor) or a technical knowledge of programming and concepts of computer science.

The U.S. National Research Council (1999) stated that 'computer literacy has acquired a skills connotation, implying competency with a few of today's basic computer applications, such as word processing and email' (p.2). Moreover, computer and information technologies continue to challenge the accuracy of these implied competencies since computer applications are moving beyond basic tasks. In recent years, computer information systems have experienced substantial growth and, consequently, attaining acceptable literacy levels has become a necessity (Kim \& Keith, 1994). The lack of updated computer literacy skills continues to be an issue in recruiting and training new employees since no standardized tests have been adopted to assess computer literacy skills of individuals.

Lankshear (1997) found that computer literacy skills in light manufacturing cooperatives are oriented toward modern business practices and that basic computer literacy skills become irrelevant when the local market is open to global competition and the workforce is displaced. Furthermore, Bolter (1991) stated that population will polarize according to literacy levels and the elite group will work and recreate itself with the computer, while the computer illiterate will, at best, be a passive user/reader of the machine. Jury (1999) asserted that literacy education is a need that resulted from the economic, social, and political pressures that continuously increase. Consequently, it is in the best interest of companies to maintain a computer literate workforce as they will become more productive and they will assume new roles (Winter, Chudoba \& Gutek, 1997).

Workers with higher computer literacy levels are able to use their computers in more sophisticated manners (McGrath, 1990). Conversely, the lack of computer literacy severely underutilizes equipment and diminishes desired results. Andersen (1990) suggested that computer literate workers possess both concrete and abstract knowledge of computers and are able to apply their knowledge to new situations without experiencing hardship. In addition, Branchean \& Wetherbe (1987) concluded that workers will experience different adoption levels of computers and new technologies in organizations with decentralized forms of work.

Many colleges and universities require incoming adult students to demonstrate a prescribed level of computer proficiency (Ornes \& Gassert, 2007). Currently, many educational institutions offer introductory computer courses to assist students in meeting this requirement. Other institutions are considering eliminating introductory computer courses with the expectation that adult students will demonstrate adequate computer knowledge through the proficiency examination (Henson \& Kamal, 2010). In addition, the assumption that incoming college students, particularly adult business students, possess adequate computer skills has been made by many college administrators and professors (Lynam, 2003, Pierce, Lloyd, \& Solak, 2001).

According to Phillips (2001), the expectation of computer literacy is both a burden and an opportunity. The specific technology installed in any workplace constantly changes in sophistication and function. 
Dickerson (2004) agrees that employees need computer skills and that it is outside the realm of Information Technology (IT) departments to provide training on basic computing skills. Moreover, the level of computer literacy is an important variable in a number of settings. Self-reported computer literacy provides some insights on the different attitude toward adopting new changes in the workplace as they relate to technological progress and advance.

Schleife (2008) stated that the use of information and communication technologies has transformed the economic conditions of firms and the private life of individuals. People will be computer literate with respect to their own needs, interests and goals (NRC, 1999). Consequently, large discrepancies are now present between different population groups and their computer literacy levels in the workplace. Moreover, the social setting in which a person works and lives will influence what computer literacy is for that person. Lastly, Kanter (1996) stressed the need for reducing the gap in computer literacy levels as a way to achieve success in the marketplace.

\section{METHODOLOGY}

This study is conducted in two higher education institutions that offer accelerated undergraduate business programs for adult students. These institutions are located in Illinois (USA) and Memmingen (Germany). These cities were chosen due to the availability of adult business students currently employed in business organizations and the immediate access to respondents for this study. Furthermore, both institutions offer courses to improve computer literacy of incoming business students. Therefore, it is of critical importance to assess current levels of computer literacy of students while planning for future curriculum changes and allocation of resources in these institutions.

In the USA, higher education institutions continue to grow their fast track undergraduate business programs for non-traditional students (adult students), since current economic conditions are forcing working adults to return to school to pursue higher education degrees in marketable fields of work. Moreover, Illinois is an industrial and academic hub for the Midwest region of the USA and the strong availability of respondents is conducive to this line of research. Participant institutions are not identified in this study due to confidentiality clauses.

Germany has been the manufacturing center for Europe and the entrepreneurial light of the region. The city of Memmingen has experienced steady growth in its manufacturing sector during the last decade and higher education institutions have adjusted their curriculums to provide training in computer literacy for incoming college students. Further, adult students are a fast growing sector in the economy since many new higher education institutions are making degrees available to match industry trends and higher career marketability in Germany.

\section{Sample For The Study}

For the purpose of this study, a sample of convenience was used to conduct the computer literacy assessment. Figure 1 shows how samples were matched (i.e., equal number of respondents randomly matched from each sample) for more accurate comparisons while avoiding the variance error that results from uneven sample size. Table 1 show the demographic information of the two groups of adult students (business majors) currently employed in business organizations in Illinois (USA) and Memmingen (Germany). The scope of this study limited the assessment of computer literacy only to these two groups of students due to their direct interaction with computers and computer-based systems of production. Other adult students pursuing different careers were not considered for this study.

To comply with general normal distribution requirements, it was expected that at least a minimum of 30 individuals from each group, Illinois (USA) and Memmingen (Germany) participated in this study. However, confidentiality clauses precluded guaranteeing that these expectations were fully met. Participation in this study was strictly voluntary and no incentives and/or other measures were permitted to assure and/or increase response rate. 


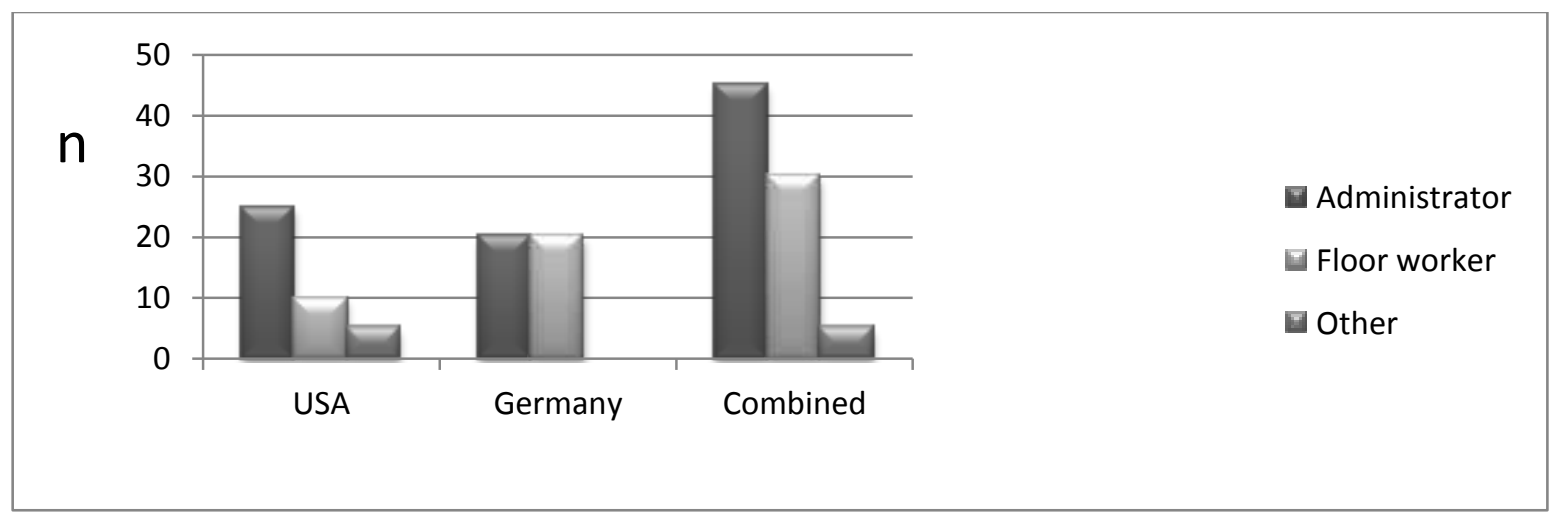

Figure 1: Survey Respondents' Jobs $(\mathbf{n}=\mathbf{8 0})$

Administrator: Individuals performing administrative and/or supervisory tasks.

Floor worker: Individuals performing general labor and maintenance related tasks (i.e., testing, set ups, trouble shooting)

Other: Individuals that did not answer the questions to identify job performed at the workplace.

\section{Distribution of the Survey}

Lead figures designated by both higher education institutions (in the USA and Germany) forwarded a copy of the survey to potential students who could participate in the study. The researcher made an electronic copy of the survey available to the lead persons in both institutions. These lead persons distributed a copy of the survey via email. Thereafter, lead persons collected and forwarded to the researcher all responses from participants, eliminating any identifying information from the participants. The researcher had no access to the distribution of the survey, nor to the immediate collection of the responses or direct contact with the participants.

An adapted version of the survey on computer literacy from the Florida state college was used for this study. The survey has been extensively tested for reliability and validity. Internal consistency was typically assessed by calculating alpha coefficients which could range from 0.00 to 1.00 . Measures of 0.70 on new measures were deemed respectable (Nunnally, 1978). For this survey, the majority of subscales had yielded alpha coefficients of 0.80 or higher. Moreover, Vogt (1993) stated that content validity was addressed when the items in a scale or measure accurately represented the phenomenon measured, suggesting that it was not a statistical property as much as it was a qualitative judgment.

The survey assessed computer literacy for adult students through four subscales which were name dependent variables (DVs) in this study: DV1= General Computer Skills, DV2= File Management- word processing and printing skills, DV3= Online Communication skills, and DV4 = Information literacy skills. Furthermore, the independent variables (IVs) were the computer literacy outcomes for the different groups in the study - IV1 = Adult business students in Germany and IV2 = Adult business students in the USA.

Because the study examined possible differences and/or similarities, a MANOVA (Multivariate analysis of variance) design was used to determine if the means of these groups were the same. If so, the study could conclude that the populations were the same and that no differences existed in computer literacy between groups (NCSS, 2005). The number-crunching statistical software (NCSS) was used to conduct MANOVA. Furthermore, the null hypothesis for this study is:

- $\quad$ There is no difference in computer literacy between adult business students in the USA and in Germany.

To examine this claim, the following research questions were addressed:

- What are the computer literacy differences and/or similarities of the American and German adult business students?

- How can computer literacy differences and/or similarities be explained, if any, between groups of adult business students in the USA and Germany? 


\section{DISCUSSION OF FINDINGS}

From the demographics information found in Table 1, the results from the study suggested that there are differences between the groups of adult business students in the USA and Germany. Most of the differences are shown in years of formal education and length of employment. These differences could contribute to the literacy levels workers possess. In addition, lower employee retention rates and high mobility may discourage emphasis on trainings and the development of new computer skills.

Table 1: Demographic Information of Survey Respondents $(\mathbf{n}=\mathbf{8 0})$

\begin{tabular}{|c|c|c|}
\hline $\begin{array}{l}\text { Demographic } \\
\text { Information }\end{array}$ & $\begin{array}{l}\text { Respondents in } \\
\text { IIIinois, USA }\end{array}$ & $\begin{array}{l}\text { Respondents in } \\
\text { Memmingen, Germany }\end{array}$ \\
\hline Gender & $\begin{array}{l}45 \% \text { Males } \\
55 \% \text { Females }\end{array}$ & $\begin{array}{l}40 \% \text { Males } \\
60 \% \text { Females }\end{array}$ \\
\hline Age & $\begin{array}{ll}80 \% & 25-35 \text { years old } \\
20 \% & \text { No response }\end{array}$ & $100 \% 25-35$ years old \\
\hline Years of Education & $\begin{array}{l}40 \% \text { (0 to } 10 \text { years) } \\
60 \% \text { ( } 11 \text { to } 20 \text { years) }\end{array}$ & $\begin{array}{l}20 \% \text { (0 to } 10 \text { years) } \\
80 \% \text { ( } 11 \text { to } 20 \text { years) }\end{array}$ \\
\hline $\begin{array}{l}\text { Years of professional } \\
\text { experience }\end{array}$ & $\begin{array}{l}80 \% \text { (6 to } 10 \text { years) } \\
20 \% \text { No response }\end{array}$ & $100 \%$ (6 to 10 years) \\
\hline $\begin{array}{l}\text { Time with current } \\
\text { Employer }\end{array}$ & $\begin{array}{l}20 \%(+7 \text { years }) \\
80 \% \text { other }\end{array}$ & $100 \%(+7$ years $)$ \\
\hline
\end{tabular}

Tables 2 and 3 show statistically significant mean differences between groups of business students in the USA and Germany. Consequently, the Null Hypothesis 1 was rejected. This fact suggested that computer literacy differences existed between the American and German adult business students.

Table 2: Test Statistics

\begin{tabular}{|l|l|l|}
\hline Test Statistics & F-ratio & Probability level (p) \\
\hline Wilks' Lambda & 6.63 & 0.0011 \\
\hline Hotelling-Lawley trace & 10.22 & 0.0020 \\
\hline Pillai's trace & 5.59 & 0.0005 \\
\hline Roy's largest root & 31.10 & 0.0000 \\
\hline
\end{tabular}

Table 3: Summary of Anova Results (n=80)

\begin{tabular}{|l|c|c|c|}
\hline Dependent Variables & M & SE & \multicolumn{1}{c|}{$\boldsymbol{p}$} \\
\hline DV1 & 8.70 & 0.95 & $0.036^{*}$ \\
\hline DV2 & 8.75 & 0.95 & $0.003^{*}$ \\
\hline DV3 & 8.75 & 0.95 & $0.042^{*}$ \\
\hline DV4 & 8.70 & 0.95 & $0.002^{*}$ \\
\hline
\end{tabular}

*Statistical significant at the 0.05 level

Research Question \#1: What are the Computer literacy differences and/or similarities between the American and German adult business students?

Table 4 shows that there are significant differences in general computer skills (DV1) and file management (DV2) between the American and German adult business students. These differences can be attributed to level of interaction with computers and intended use. Cuban (1986) stated that industrialized nations are more committed to the latest technological innovations and their exposure to technology is stronger when compared to other countries with lesser economic sophistication (Albirini, 2008). However, people will be computer literate with respect to their own needs, interests and goals (NRC, 1999). Consequently, large disparities are now present between different population groups and their computer literacy levels in the workplace. 
Table 4: Summary Of Significant Differences Between Groups Of Adult Business Students (DV1, DV2)

\begin{tabular}{|l|l|l|c|}
\hline \multicolumn{1}{|c|}{ DV1- General computer skills } & $\begin{array}{c}\text { Country } \\
\text { USA/Germany } \\
\text { Significant difference }\end{array}$ & DV2- File management & $\begin{array}{c}\text { Country } \\
\text { USA/Germany } \\
\text { Significant difference }\end{array}$ \\
\hline 1. Using basic computer parts. & No & 8. Using windows explorer. & Yes \\
\hline 2. Using help menus. & No & 9 . Working with files. & Yes \\
\hline 3. Understanding file formats. & Yes & 10. Deleting files /using the bin. & Yes \\
\hline 4. Shut down a computer. & Yes & 11. Copying/pasting text blocks. & Yes \\
\hline 5. Do a re-start. & Yes & 12. Using redo/undo. & Yes \\
\hline 6. Working with program- windows. & Yes & 13. Saving and printing files. & Yes \\
\hline 7. Using context menus. & No & 14 . Using fonts and styles. & Yes \\
\hline & & 15. Creating lists. & Yes \\
\hline
\end{tabular}

Differences in file management areas also suggest that individuals with higher computer literacy levels are able to use their computers in more sophisticated manners (McGrath, 1990). Furthermore, differences in adoption levels of computers and other technologies affect basic literacy levels of individuals. Conversely, the lack of computer literacy diminishes desired results in students' performance in school and at the workplace. Andersen (1990) suggested that computer literate workers possess both concrete and abstract knowledge of computers and are able to apply their knowledge to new situations without experiencing hardship. However, individuals depend more on business organizations to update computer knowledge, as needed to perform their work, rather than in higher education institutions to provide further training on computer literacy (Henson \& Kamal, 2010). Therefore, significant different in computer literacy are evident, since there are no standardized programs to improve computer literacy levels of individuals in business organizations.

Table 5 shows that the majority of respondents were aware of the internet technology (DV3) and the issues derived from managing information (i.e., copyrights, plagiarism, privacy and security). Moreover, in more specialized tasks, there were significant differences on how individuals manage information (DV4) and how they complete office tasks. The internet has been widely available in developed nations. However, the use of information and communication technologies has transformed the economic conditions of firms and the private life of individuals in different manners (Albirini, 2008). Consequently, a wide variety of computer experiences earned in different contexts will produce different computer competencies and ultimately differences in computer literacy of individuals (Karsten \& Roth, 1998).

Table 5: Summary Of Significant Differences Between Groups Of Adult Business Students (DV3, DV4)

\begin{tabular}{|l|l|l|c|}
\hline \multicolumn{1}{|c|}{$\begin{array}{c}\text { DV3 - Online Communication } \\
\text { Skills }\end{array}$} & $\begin{array}{c}\text { Country } \\
\text { USA/Germany } \\
\text { Significant Difference }\end{array}$ & DV4 - Information Literacy Skills & $\begin{array}{c}\text { Country } \\
\text { USA/Germany } \\
\text { Significant Differences }\end{array}$ \\
\hline 17. Using internet browser. & No & 26. Open office documents. & Yes \\
\hline 18. Create an email account. & $\begin{array}{l}\text { Y7. Working with } \\
\text { messages/documents. }\end{array}$ & No \\
\hline 19. Create and send emails. & No & 28. Working with outlook calendar. & No \\
\hline 20. Using search engines. & Yes & 30. Search for information. & Yes \\
\hline $\begin{array}{l}\text { 21. Understand differences between } \\
\text { search engines and directories. }\end{array}$ & No & 31 . Using literacy databases. & Yes \\
\hline $\begin{array}{l}\text { 22. Understanding copyright } \\
\text { restrictions. }\end{array}$ & No & $\begin{array}{l}\text { 32. Analyze information and } \\
\text { sources. }\end{array}$ & Yes \\
\hline $\begin{array}{l}\text { 23. Using content in compliance to } \\
\text { copyright restrictions. }\end{array}$ & No & $\begin{array}{l}33 \text {. Using information efficiently. } \\
\text { and social aspects. }\end{array}$ & Yes \\
\hline $\begin{array}{l}\text { 24. Understanding plagiarism. } \\
\text { 25nowledge about privacy and }\end{array}$ & Yes & & \\
\hline
\end{tabular}

Research Question \#2: How can computer literacy differences and/or similarities be explained, if any, between groups of adult business students in the USA and Germany? 
Dickerson (2004) asserted that employees need computer skills and that it is outside the realm of Information Technology (IT) departments to provide training on basic computing skills. The level of computer literacy is an important variable in a number of settings and self-reported computer literacy provides some insights on the different attitudes toward adopting new technologies in the workplace. Consequently, large disparities are now present between different population groups and their computer literacy levels in the workplace. In addition, Kanter (1996) stressed the need for reducing the gap in computer literacy levels as a way to achieve success in the marketplace.

Individuals with higher computer literacy levels are able to use their computers in more sophisticated manners (McGrath, 1990). Conversely, the lack of computer literacy severely underutilizes equipment and diminishes desired results. Andersen (1990) suggested that computer literate individuals possess both concrete and abstract knowledge of computers and are able to apply their knowledge to new situations without experiencing hardship. Moreover, differences in computer literacy between adult students in the Unites States and Germany are strong indicators of current educational needs.

Brock \& Thompsen (1992) suggested that access to computers at home and other technologies also influence computer familiarity of individuals and therefore computer literacy levels. In Germany, all business organizations train and retain their workforce for longer periods of time, providing individuals with specific skills and education that suits current industry needs. Moreover, current computer literacy levels are periodically updated through company-sponsored trainings and workshops. However, Karsten \& Roth (1998) suggested that although a wide variety of computer experiences enhance self- perception of computer competencies, only those experiences in a particular context are likely to have significant impact on computer literacy levels of individuals. Conversely, in the USA, computer literacy levels varied a lot; individuals join the labor force from different backgrounds. Moreover, the short-term employability dismisses the possibility of continuous training to update computer skills.

\section{CONCLUSION}

The evolution of computer systems and other computer-related technologies has significantly transformed society and individuals (Albirini, 2008). During the past two decades, researchers have explored different areas of technology literacy. Computer and information literacy are main streams of research. However, information literacy has claimed greater attention from researchers since many of the new technologies focus more on information issues (software applications) rather than computer issues (hardware and software).

Business organizations continue to experience shortages of qualified workers. Updated knowledge and new technology skills are of great demand today. Moreover, higher education institutions continue to revise their curriculums to ensure that students are offered degrees in competitive fields of work (Recker \& Alter, 2012). Many of the changes in curriculums reflect growing concern for information technology and computer-related technologies (Miliszewska, Venables, \& Tan, 2010). However, differences in computer literacy levels of individuals pose a challenge to higher education institutions and to business organizations since there are no standardized tests to assess computer literacy skills of individuals. Therefore, addressing future needs for training and education remains an uncertain endeavor in industry and education.

Increased computer literacy allows individuals to use their computers in more sophisticated manners and to become more productive by assuming new roles in organizations (Gerrity \& Rockart, 1986). However, individuals will develop different computer literacy levels in relation to their immediate social context and to their group behavioral factors (King \& He, 2006). Moreover, it is difficult for researchers to identify and assess factors that cause people to accept new technologies (Sharkey, 2006); therefore, researchers should continuously assess computer literacy levels to better understand differences among groups of individuals and to further reduce existing gaps in knowledge.

Business organizations need employees with updated knowledge and skills. Today's dynamic environments rely on individuals to keep up with technological changes and to self-teach about such changes (Hill, 2006). Individuals are not exposed to the same level of information technology in business organizations, but everyone is in direct contact with a computer in today's business environment. The diverse generational composite has embraced 
new information technologies in different ways. While some individuals continue to resent changes in the workplace, others embrace it as the new way to achieve higher efficiencies and innovations.

Today's workforce is inclusive of three generations. This kind of diversity will change in the next decades and the need to assess computer literacy will demand additional studies in this field. Labor practices (training, updates of skills, education programs, etc.), retention rates and the nature of the work itself will influence future literacy levels. Individuals are continuously exposed to technological changes and the future trends of innovation. As a result of these changes, future studies should include the creation of new assessment questionnaires and methodologies.

The results of this study suggest that there are computer literacy differences between adult business students in the USA and Germany. Further, these results are not conclusive for all computer literacy levels in adult business students in the USA and in Germany. Several limitations of the study prevent the generalization of results. Sample size, other majors, former students and the need for more comprehensive questionnaires should be addressed in future studies. Finally, the researcher also suggests that future studies should look into other demographic factors that may affect computer literacy, such as type of education, ownership of computers at home, disposable income used for continuing education, and general attitude toward new technologies available in the market.

\section{AUTHOR INFORMATION}

Dr. Barrera is an assistant professor of International Business at Elmhurst College's Department of Business. He teaches courses in strategy and international business for the MBA program and the MsSCM program. Dr. Barrera has also extensive experience lecturing in Europe and Latin America. His consulting work focuses on small medium size companies in Germany and in Mexico. He is also a member of the Academy of Management and the Academy of International Business. E-mail: barreraj@elmhurst.edu

\section{REFERENCES}

1. Albirini, A. (2008). The Internet In Developing Countries: A Medium Of Economic, Cultural And Political Domination. International Journal of Education and Development using ICT, 4(1).

2. $\quad$ Andersen Consulting (1990), The changing shape of IS: Redefining technology leadership. (3rd ed.). USA.

3. Banta, T. \& Howard, M. (2004). Assessing Information Literacy And Technological Competence. Assessment Update, 16(5) 3-14.

4. Brancheau, J., \& Wetherbe, J. (1987). Key Issues In Information Systems - 1986. MIS Quarterly, 11(1) 2347.

5. Bolter, J. (1991). Writing Space: the computer, hypertext, and the history of writing. Lawrence Erlbaum Assoc.

6. Brock, J. F. \& Thomsen, W. E. (1992). The Effects Of Demographics On Computer Literacy Of University Freshmen. Journal of Research on Computing in Education, Summer 24(4) 563-571.

7. Brown, S. (2000). Ford's Plan To Cultivate Computer Literacy. Electronic Business, 26(4) 138.

8. Childers, S. (2003). Computer literacy: necessity or buzzword?. Information Technology and Libraries, 22(3) 100-104.

9. Computer literacy survey (2010). Florida State College: A division of Florida state college at Jacksonville. Florida, USA.

10. Cuban, L. (1986). Teachers and machines: The classroom use of technology since 1920. New York, NY: Teachers College Press.

11. Davis, T. R. (1991). Information Technology And White-Collar Productivity. Academy of Management Executive, 5(1) 55-67.

12. Demiray, E. (2010). Information Technologies \& Women. Journal of Information Technology, 7(1).

13. Dickerson, C. (2004). Why Can’t Johnny Compute? InfoWorld, 26(41) 24.

14. Gerrity, T. P., \& Rockart, J. F. (1986). End-User Computing: Are You A Leader Or A Laggard? Sloan Management Review, 27(4) 25-34.

15. Hardy, J. L. (1995). Assessment Of The Level Of The Actual And Desirable Levels Of Computer Literacy, USAge And Expected Knowledge Of Undergraduate Students Of Nursing. Medinfo, 8(2) 1326-1330. 
16. He, J. \& Freeman, L. (2006). Are Men More Technology-Oriented Than Women? The Role Of Gender On The Development Of General Computer Self-Efficacy Of College Students. Journal of Information Systems Education. 21(2).

17. Henson, K. and Kamal, M. (2010) Closing The Gap - Information Systems Curriculum And Changing Global Market, American Journal of Business Education 3(5) 17-20

18. Hignite, M. \& Echternacht, L. (1992). Computer Attitudes And Literacy Assessment: Are Tomorrow's Business Teachers Prepared? Journal of Education for Business, 67(4) 249-253.

19. Hill, Charles W.L. (2009). Global Business Today. 6th edition, McGraw Hill.

20. Hunt, C. S., \& Perreault, H. R. (1999). Organizational \& End-User Information Systems: A Compendium Of Resources And Materials. Office Systems Research Journal, 17(1) 37-49.

21. Jury, M. (1999). A Different Set Of Literacy Demands. Journal of Adolescent and Adult Literacy, 42(5) 364-370.

22. Kanter, J. (1996). Guidelines For Attaining Information Literacy. Information Strategy, 12, 6-11.

23. Karsten, R. \& Roth, R. (1998). The Relationship Of Computer Experience And Computer Self-Efficacy To Performance In Introductory Computer Literacy Courses. Journal of Research on Computing in Education, 31(1) 14-25.

24. Kay, R. (1990). The Relation Between Locus Of Control And Computer Literacy. Journal of Research on Computing in Education, Summer, 22(2) 464-475.

25. Kim, C. S. \& Keith, N. K. (1994). Computer Literacy Topics: A Comparison Of Views Within A Business School. Journal of Information Systems Education, Summer, 6 (2) 55-57.

26. King, W.R., \& He, J. (2006). A Meta-Analysis Of The Technology Acceptance Model. Information and Management, 43, 740-755.

27. Lankshear, C. (1997). Changing literacies. Maidenhead. Berks, UK: Open University Press.

28. Lucas, R. E. (1976). On The Size Distribution Of Business Firms. The Belt Journal of Economics, 9, 508523.

29. Lynam, L. (2003). Required software proficiency in general education and business courses. In McGill (Ed.), Current Issues in IT Education. Hershey, PA: IRM Press.

30. Marshall, K. P. (1993). Preparing For Change In Computer Education For Business. Journal of Education for Business, 68(6) 376-380.

31. McGrath, J. E. (1990). Time matters in groups intellectual teamwork: The social and technological foundations of cooperative work, Hillsdale, NJ: Lawrence Erlbaum, 23-61.

32. Miliszewska, I., Venables, A., \& Tan, G. (2010). Didactics Of Information Technology (IT) In A Science Degree: Conceptual Issues And Practical Application. Journal of Information Technology Education: Innovations in Practice, 9, 79-89.

33. Navaro, L (1997). Tapınağın Öbür Yüzü kadınlarve Erkekler Üzerine. Istanbul, Turkey: Varlik.

34. NRC - National Research Council Committee on Information Technology Literacy. (1999). Being fluent with information technology. Washington, DC: National Academy Press.

35. NCSS (2005) Number Crunching Statistical Software.

36. Norales, F. O. (1987). Postsecondary Students'Attitudes Toward Computers. The Journal of Computer Information System. Summer, 15-20.

37. Norman, D. (1984). Stages And Levels In Human-Machine Interaction. International Journal of Manmachine Studies, 21, 365-375.

38. Nunnally, J. C. (1978). Psychometric Theory ( $2^{\text {nd }}$ ed.). New York, USA: McGraw-Hill.

39. O'Connor, L. (2007). The Diffusion Of Information Literacy In Academic Business Literature. Journal of Business \& Finance Librarianship, 13(2) 105-125.

40. Oni, C. S. (2000). Effective Vocational-Technical Education For National Technological Development In Nigeria. Ife Journal of Curriculum Studies and Development, 1(2) 48-50.

41. Ornes, L. \& Gassert, C. (2007). Research Briefs. Computer Competencies in a BSN Program. 46(2).

42. Phillips, J. (2001). Embracing The Challenge Of Leadership. Information Management Journal, 35(3) 5862.

43. Pierce, E.M., Lloyd, K.B., \& Solak, J. (2001). Lessons Learned From Piloting A Computer Literacy Test For Placement And Remedial Decisions. Journal of Information Systems Education, 12(2) 81.

44. Recker, J. \& Alter, S. (2012). Using The Work System Method With Freshman Information Systems Students. Journal of Information Technology Education: Innovations in Practice, 11. 
45. Sharkey, J. (2006). Toward Information Fluency: Applying A Different Model To An Information Literacy Credit Course. Journal of Academic Librarianship, 32(4) 447.

46. Schenk, M. (2007). Information and Computer Literacy - A Comparative Analysis On Educational Level In The USA Of America And Germany. German Institute for Adult Education, Trends in Education Study.

47. Schleife, K. (2008). Empirical analyses of the digital divide in Germany-Age-specific and regional aspects. Techische Universität Darmstadt.

48. Venables, A., \& Tan, G. (2009). Realizing Learning In The Workplace In An Undergraduate IT Program. Journal of Information Technology Education: Innovations in Practice, 8, 17-26.

49. Vogt, W. P. (1993). Dictionary of statistics and methodology (1st ed., Vol. 1). CA, USA: Newbury park: Sage Publications. Washington, DC: SETAR. (Original work published 1979).

50. Wallace, P. \& Clariana, R. (2005). Perception Versus Reality - Determining Business Students' Computer Literacy Skills And Need For Instruction In Information Concepts And Technology. Journal of Information Technology Education. 4, 140-151.

51. Winter,S., Chudoba, K \& Gutek, B. (1997). Misplaces Resource? Factors Associated With Computer Literacy Among End Users. Information \& Management Review, 32, 29-42.

52. Wolfe, H. W. (1992). Computer Literacy For The 1990s. Journal of Information Systems Education. 4(1), $1-5$. 


\section{NOTES}

